Article

\title{
Impact of Vibration Time on Compressive Strength of Hardened Sandcrete Building Blocks
}

\author{
Alohan Omoregie \\ School of Built Environment and Engineering, University of Bolton (UK), UAE Campus, Al \\ Hudaiba-Bareraat, P.O. Box 16038, Ras al Khaimah, UAE; E-Mail: a.omoregie@bolton.ac.uk
}

Received: 2 February 2012; in revised form: 9 March 2012 / Accepted: 30 April 2012 /

Published: 9 May 2012

\begin{abstract}
The majority of the sandcrete blocks used in the Nigerian building industry fall short of the minimum specification standards. There is evidence to suggest a wide variation in compressive strength from one block manufacturer to another and also within block samples from a single source. This problem has been attributed to poor quality control and substandard constituent materials. Also very alarming is the ignorance surrounding the usage and engineering properties of some of the widely used fine aggregate deposits. As a way forward, this paper aims to re-establish the impact of vibration time in sandcrete block production using six fine aggregate deposits found within Benin City (Midwestern Nigeria) and their various pair combinations. Some of the basic properties like silt content, grading parameters - co-efficient of uniformity $\left(\mathrm{C}_{\mathrm{u}}\right)$, curvature co-efficient $\left(\mathrm{C}_{\mathrm{c}}\right)$ and the fineness modulus $\left(\mathrm{F}_{\mathrm{m}}\right)$ - of these fine aggregates were established by laboratory means. In addition, the wet and dry compressive strength of these sandcrete blocks made from these sands were established. A total of 1,080 block samples produced under very controlled conditions were used in this investigation. It was revealed that the utility value of sand can be improved when the weaker and commonly used sands were combined with those that are better, more expensive and less frequently used at different vibration periods and ratios. Findings further revealed that sand types and the sand combination approach adopted were very significant to grading parameters and strength; at a much higher vibration time the compressive strength and durability properties were also considerably improved.
\end{abstract}

Keywords: fine aggregates; uniformity coefficient; curvature coefficient; fineness modulus; vibration time; compressive strength; silt contents; Nigeria 


\section{Introduction}

Poor quality control and the use of sub-standard building materials are attributed to the high failure rates of buildings in Nigeria [1-4]. Also [5] as cited in [6] were of the view that structural failure is a direct function of constituent material failures and the material-to-material interactions within the structural unit. For this reason, if constituent materials of any structural unit are improved, it will ultimately improve the structural value of the whole unit. For some time now, the majority of the sandcrete blocks used primarily for load bearing walls (structural masonry) and in a few cases as partition walls, in the Nigerian building industry often fall short of specification standards recommended by the Nigerian Federal Ministry of Works [3]. Some of these blocks even fail while being transported due to self-weight. It is not surprising therefore, to see reoccurring cases of building collapse; most especially due to failures of load bearing walls made from these blocks.

Freestanding walls and building structures with sandcrete load bearing walls are very common in Nigeria because they are simple to construct and easily affordable. Even sandcrete skin panels and blocks can sometimes be used to provide aesthetic value to buildings and also, when adequately prepared, to control moisture infiltration and wind action. This utility value of sandcrete in comparison to its cost and its adaptability to climatic factors is responsible for its wide application; most especially in small to medium size buildings in countries within tropical rainforests (i.e., Nigeria, Ghana, Cameroon, Ivory Coast, etc.) where a considerable amount of precipitation and high average temperatures are predominant. Other forms of modern walling materials exist such as clay masonry units, concrete masonry units (dense and lightweight aggregates), autoclaved aerated concrete masonry units, manufactured and natural stone masonry units, local studs and lateritic mud. However, these are hardly ever used for domestic buildings due to cost, the need of technical skills and in some cases aesthetic values and technology. In fact, [21] as cited in [22] also emphasized the wide spread use of sandcrete blocks. They were of the view that close to 90 percent of physical infrastructure, predominantly housing in Nigeria, is made of hardened sandcrete blocks (see Figure 1). 
Figure 1. Typical housing development (predominantly of sandcrete blocks) in a semi-urban area in Nigeria.

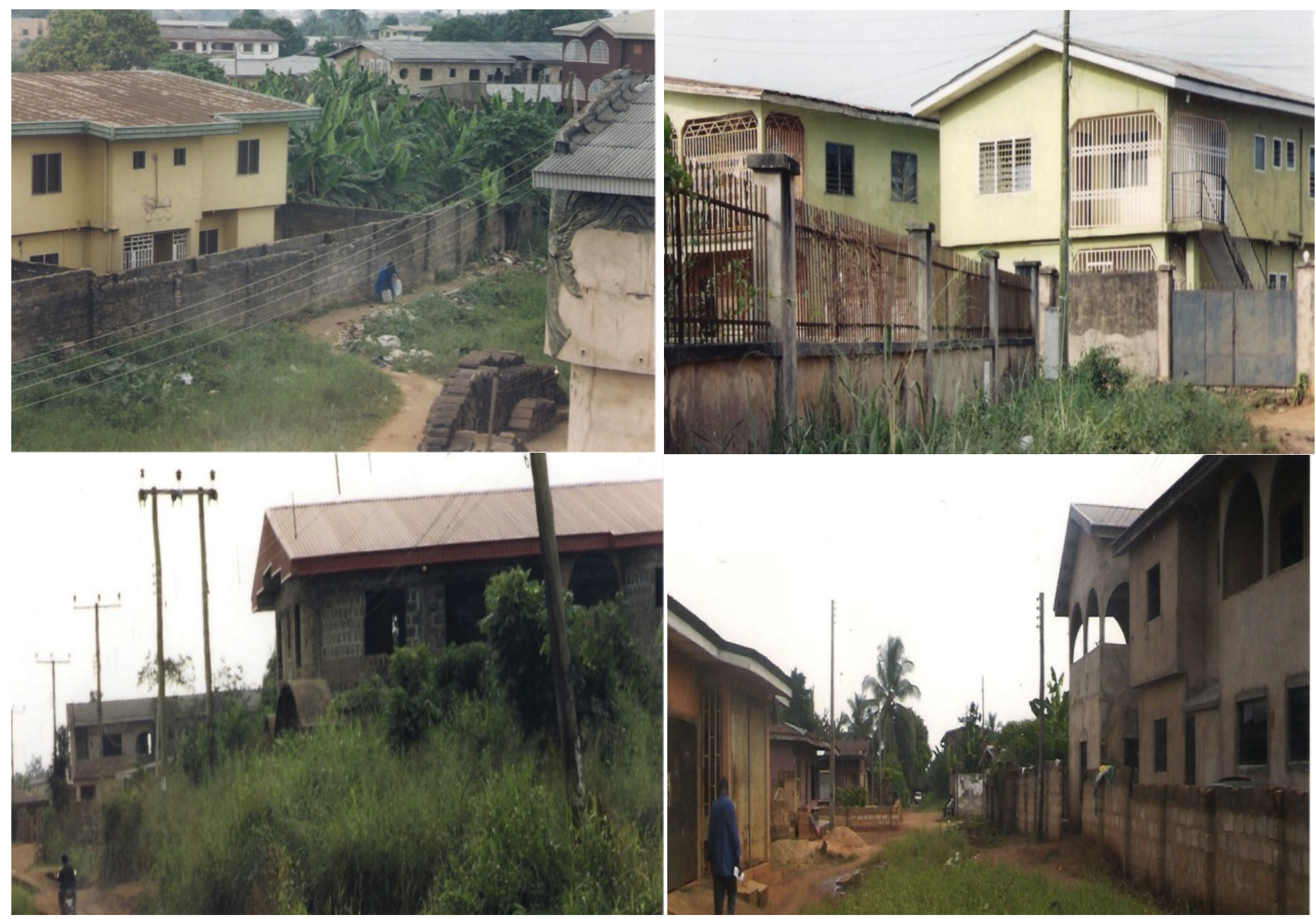


Therefore, because of their common use, the need for masonry studies to address these problems is overwhelming. This is particularly true as several studies have established that most sandcrete blocks produced in Nigeria are substandard.

These inadequacies often stem from the quality and quantity of the materials used in the production of these blocks, i.e. fine aggregate, cement and water. The Portland cement predominantly used in the manufacture of sandcrete blocks is often deficient in basic characteristics such as its soundness: leading to excessive change in volume; particularly expansion of the cementious paste after setting. This manifests itself in time by cracking and disintegration of surfaces. Even the mixing water frequently employed in sandcrete block manufacture is often unsuitable. Most water used in sandcrete production in Nigeria is waste water significantly polluted with organic materials, alkalis, acids and glycerine (grease). This is particularly true due to the fact that portable water is almost a luxury in Nigerian rural and semi-urban areas. Furthermore, substandard constituent materials such as fine aggregate with poor engineering properties is also very commonly used. Fine aggregate constitutes 60 to $80 \%$ of the volume of sandcrete and thus functions as an inert material acting as a filler. Sadly however, the majority of this fine aggregate employed in sandcrete block making in Nigeria is also contaminated with organic materials such as humus, dirt, silt, clay, mica and salts. This continues despite the fact that it is a widely accepted fact that choice (quality) of sand and its grading has a considerable consequence on the consistence (workability) of fresh mortar and finishing properties of hardened mortar [23] as some sand may require undue (uneconomic) adjustment of mix ratio.

As reiterated previously, the quantities of material (mix ratios) can also impact on the overall quality of these blocks: water-cement ratio, wrong mix proportions (sand-cement ratio). Inadequate and uncontrolled curing conditions and inadequate compaction could also influence the overall quality of the sandcrete blocks. As a way forward, this paper concentrates on the application of vibration time in sandcrete block production to enhance durability and compressive strength through compaction. To achieve this, the following objectives are to be established in this paper:

1. The impact of vibration time on six different most commonly used fine aggregates found around the Benin City metropolis;

2. The impact of vibration time on multiple two-aggregate combinations.

However, the influence of fine aggregate combinations on particle size distribution, grading parameters and compressive strength of sandcrete blocks have been ascertained in previous studies carried out by [7]. Thus, what is principally being examined in this paper is the impact of vibration time on the compressive strength of sandcrete blocks.

Masonry studies in various parts of Nigeria revealed that the majority of blocks do not meet the minimum standard strength of $1.7 \mathrm{~N} / \mathrm{mm}^{2}$ or the required mean strength of $2.1 \mathrm{~N} / \mathrm{mm}^{2}$. Moreover, the strength of the samples varied from one block manufacturer to another and similar strength variations also exist within samples from a single source $[2,3,7,8]$.

For example, in the eastern part of Nigeria (Enugu and its environs) studies revealed that none of the sandcrete block samples selected by random sampling from the twenty five block molding manufacturers in the city met the twenty-eight day minimum strength of $1.7 \mathrm{~N} / \mathrm{mm}^{2}$ [2,7]. There were recurring cases of variation from one manufacturer to another and even within the same source. 
Similarly, recent assessments of the quality of sandcrete blocks in the north central part of Nigeria (Kaduna state), using stratified-purposeful sampling to select locations and block molding industries within Kaduna state, revealed very low durability and wet compressive strength properties. A total of five block molding manufacturers and ninety five randomly selected block samples were used in this investigation [9]. Further investigations carried out in Minna, Niger State (north-western part of Nigeria) also revealed that commercially produced blocks within the town were far below standard minimum requirements [10]. [3] as cited in [7] revealed, from similar studies covering six northern states, that the blocks produced in the northern part of Nigeria were of very low quality; a total of 306 randomly selected block samples were used for this investigation.

Some related studies carried out in the mid-western part of Nigeria (Benin City, Ekpoma, Ughelle, Effurun and Warri towns) revealed similar findings in the east, north central and north western parts of Nigeria.

In England for instance, masonry units have to comply with the relevant BS EN Standards. Where they fail to conform to these standards, they are normally subjected to appropriate tests to ascertain that the units satisfy the engineering requirements. Normally, specifications for structural masonry units are a function of the designers' requirements which are normally based on the strength (compressive and/or flexural) and durability (the exposure conditions that the units will be subjected to). However, strength and durability are dependent on the mortar used and masonry units' properties. In Nigeria, due to lack of knowledge and for economic reasons, prospective developers hardly consult relevant expertise for small scale or domestic projects where sandcrete masonry is often employed. Most disturbing of all, is that some of these blocks tend to fail due to their own self weight. If this scenario was not the case, structural engineers would have been sufficiently equipped in expertise to improve what is available with adequate structural design. The minimum masonry mortar compressive strength at 28 days in the UK and most European countries is $2 \mathrm{~N} / \mathrm{mm}^{2}$ (mortar designation (iv); compressive strength class M2) [24,25]. By implication, the minimum standard compressive strength requirements in Nigeria compete favorably with other parts of the world if adequately adhered to.

In all, it was observed that block manufacturers in Nigeria do not comply with the basic principles of block production and often employ sub-standard constituent materials. Since fine aggregate (sand) makes $80 \%$ of the sandcrete, it is important to briefly attempt to explain the natural formation of these materials in the environment. This paper is subdivided into six parts, namely: introduction; sources of fine aggregate; program of investigation; methodology; discussion; recommendations and conclusion.

\section{Sources of Sand}

The principal sources and transportation of coastal sediments like sand are predominantly rivers and streams. Ideally, these coastal sediments eventually get transported to the deep sea. Sand is also produced through gradual wearing away and weathering of rock formation and cliff naturally out in the open shore [26]. Through the action of wave, wind and currents these sands are able to move along (up and down) the coast; a process commonly referred as longshore transport. When obstacles like natural or artificial coastal features obstruct the path of longshore transport, the resulting friction gradually creates accumulations of up-drift sand and similar erosion leading to the accumulation of sand also takes place down-drift of the shore. This periodic movement reduces the sharp edges of the sand 
particles and thus its grit; making it smoother and less tough than it would normally be. This type of sand is called beach sand-popularly known as erosion sand.

Similarly, through the action of wind, tides and currents these beach sands can also be transported offshore (as submerged sandbars) and back onshore as berm or ridges of sand parallel to the shoreline caused by calm weather and low energy waves. This type of sand is usually outside the reach of normal waves and tide because it is deposited as berm on the upper part of the beach. It is therefore less exposed to periodic movement occasioned by longshore transport and, by implication, often retains its original physical properties [26] to a considerable degree. This type of sand is what is frequently referred to as river sand. Depending on the surrounding rocks and environmental conditions, river sand has a highly variable grain size composition. Overall therefore, one caln say that the physical characteristics of sand are also a dependent function of its transportation and deposition mechanism. This transportation process in the tropics is dependent on rainfall intensity, surface runoff, soil erodability, slope gradient and length, vegetation and groynes (conservation measures).

\section{Program of Investigation}

This investigation was carried out using the following sand deposits in Benin City: Okhuahia river sand (OKRS); Okhuahia erosion sand (OKES); Ovia river sand (OVRS); Ovia erosion sand (OVES); Okhoro erosion sand (OES); Ikpoba flood erosion sand (IFS). These sand designations are a function of their location. OKRS and OVRS are less frequently used sands compared to OES and IFS in Benin City. It is important to note that previous studies [7] have ascertained the properties of these sands and that OKRS and OVRS have better engineering properties compared to OES and IFS. The properties of OKES and OVES fell in between both pairs above. The sandcrete block types used in this investigation are $150 \mathrm{~mm}$ and $225 \mathrm{~mm}$ in width. See Tables 1-4 below for the various frames of block samples tested. It is also important to state that the frame in Table 1 is only for a single block type at a single vibration period and 10, 20 and 25 seconds' vibration periods were implemented in this investigation. Using 54 blocks for each vibration period as shown in Table 1 , a total of $(54 \times 3)=162$ block samples were produced under controlled conditions, for a single block type. Since there are two block types $(225 \mathrm{~mm}$ and $150 \mathrm{~mm})$ a grand total of $(162 \times 2)=324$ blocks were produced without combining fine aggregates (see Table 1).

Table 1. Number of blocks per vibration period for each block type without combining fine aggregates.

\begin{tabular}{ccccc}
\hline \multicolumn{5}{c}{ Number of blocks for various testing periods } \\
\hline Sand & 7-day & 14-day & 28-day & $\begin{array}{c}\text { Number of blocks per } \\
\text { vibration period }\end{array}$ \\
\hline OKRS & 3 & 3 & 3 & 9 \\
OVRS & 3 & 3 & 3 & 9 \\
OKES & 3 & 3 & 3 & 9 \\
OVES & 3 & 3 & 3 & 9 \\
OES & 3 & 3 & 3 & 9 \\
IFS & 3 & 3 & 3 & 9 \\
Total & & & & 54 \\
\hline
\end{tabular}


Table 2. Number of $225 \mathrm{~mm}$ blocks from sand combinations for various testing periods and vibration times.

\begin{tabular}{cccccc}
\hline \multicolumn{5}{c}{ Number of blocks for various testing periods } \\
\hline $\begin{array}{c}\text { Sand } \\
\text { combinations }\end{array}$ & $\begin{array}{c}\text { Ratio of } \\
\text { mixture }\end{array}$ & 7-day & 14-day & 28-day & $\begin{array}{c}\text { Number of } \\
\text { blocks per sand } \\
\text { type }\end{array}$ \\
\hline OKRS and IFS & $01: 01$ & 3 & 3 & 3 & 9 \\
OKRS and IFS & $01: 02$ & 3 & 3 & 3 & 9 \\
OKRS and IFS & $02: 01$ & 3 & 3 & 3 & 9 \\
OKRS and OES & $01: 01$ & 9 & 9 & 9 & 27 \\
OKRS and OES & $01: 02$ & 9 & 9 & 9 & 27 \\
OKRS and OES & $02: 01$ & 9 & 9 & 9 & 27 \\
OVRS and IFS & $01: 01$ & 3 & 3 & 3 & 9 \\
OVRS and IFS & $01: 02$ & 3 & 3 & 3 & 9 \\
OVRS and IFS & $02: 01$ & 3 & 3 & 3 & 9 \\
OVRS and OES & $01: 01$ & 9 & 9 & 9 & 27 \\
OVRS and OES & $01: 02$ & 9 & 9 & 9 & 27 \\
OVRS and OES & $02: 01$ & 9 & 9 & 9 & 27 \\
OKRS and OVES & $01: 01$ & 9 & 9 & 9 & 27 \\
OKRS and OVES & $01: 02$ & 9 & 9 & 9 & 27 \\
OKRS and OVES & $02: 01$ & 9 & 9 & 9 & 27 \\
OVRS and OVES & $01: 01$ & 9 & 9 & 9 & 27 \\
OVRS and OVES & $01: 02$ & 9 & 9 & 9 & 27 \\
OVRS and OVES & $02: 01$ & 9 & 9 & 9 & 27 \\
Total number of blocks tested & & & & 378 \\
\hline
\end{tabular}

Table 3. Number of $150 \mathrm{~mm}$ sandcrete blocks from sand combinations for various testing periods and vibration times.

\begin{tabular}{cccccc}
\hline \multicolumn{5}{c}{ Number of blocks for various testing periods } \\
\hline $\begin{array}{c}\text { Sand } \\
\text { combinations }\end{array}$ & $\begin{array}{c}\text { Ratio of } \\
\text { mixture }\end{array}$ & 7-day & 14-day & 28-day & $\begin{array}{c}\text { Number of } \\
\text { blocks per sand } \\
\text { type }\end{array}$ \\
\hline OKRS and OES & $01: 01$ & 9 & 9 & 9 & 27 \\
OKRS and OES & $01: 02$ & 9 & 9 & 9 & 27 \\
OKRS and OES & $02: 01$ & 9 & 9 & 9 & 27 \\
OVRS and OES & $01: 01$ & 9 & 9 & 9 & 27 \\
OVRS and OES & $01: 02$ & 9 & 9 & 9 & 27 \\
OVRS and OES & $02: 01$ & 9 & 9 & 9 & 27 \\
OKRS and OVES & $01: 01$ & 9 & 9 & 9 & 27 \\
OKRS and OVES & $01: 02$ & 9 & 9 & 9 & 27 \\
OKRS and OVES & $02: 01$ & 9 & 9 & 9 & 27 \\
OVRS and OVES & $01: 01$ & 9 & 9 & 9 & 27 \\
OVRS and OVES & $01: 02$ & 9 & 9 & 9 & 27 \\
OVRS and OVES & $02: 01$ & 9 & 9 & 9 & 27 \\
Total number of blocks tested & & & & 324 \\
\hline
\end{tabular}


Table 4. Number of $225 \mathrm{~mm}$ blocks at the 14-day testing period of various sand combinations for the wet compressive strength.

\begin{tabular}{ccc}
\hline Sand combinations & Ratio of mixture & 14-day \\
\hline OKRS and IFS & $01: 01$ & 9 \\
OKRS and IFS & $01: 02$ & 9 \\
OKRS and IFS & $02: 01$ & 9 \\
OKRS and OES & $01: 01$ & 9 \\
OKRS and OES & $01: 02$ & 9 \\
OKRS and OES & $02: 01$ & 9 \\
Total number of blocks tested & 54 \\
\hline
\end{tabular}

$\therefore$ Total block samples tested $=324+378+324+54=1080$ blocks

\section{Methodology}

\subsection{Sampling of Fine Aggregate}

The Riffler process was adopted as the sampling method for this investigation.

\subsection{Sieve Analysis}

The particle size distribution was carried out mechanically through a stack of British standard sieves as described in [11]. This process was conducted for all the sands and the various sand combinations in order to understand their grading and improvements. Some of these grading and improvements are represented as curves on the conventional semi-logarithmic plot (Figures 2-5). The grading for the various sands and their relative combinations were numerically expressed in terms of grading coefficients like the uniformity coefficients $\left(\mathrm{C}_{\mathrm{u}}\right)$, curvature coefficients $\left(\mathrm{C}_{\mathrm{c}}\right)$ and the fineness modulus $\left(\mathrm{F}_{\mathrm{m}}\right)$.

Figure 2. Grading curve for OKRS on a semi-logarithmic plot.

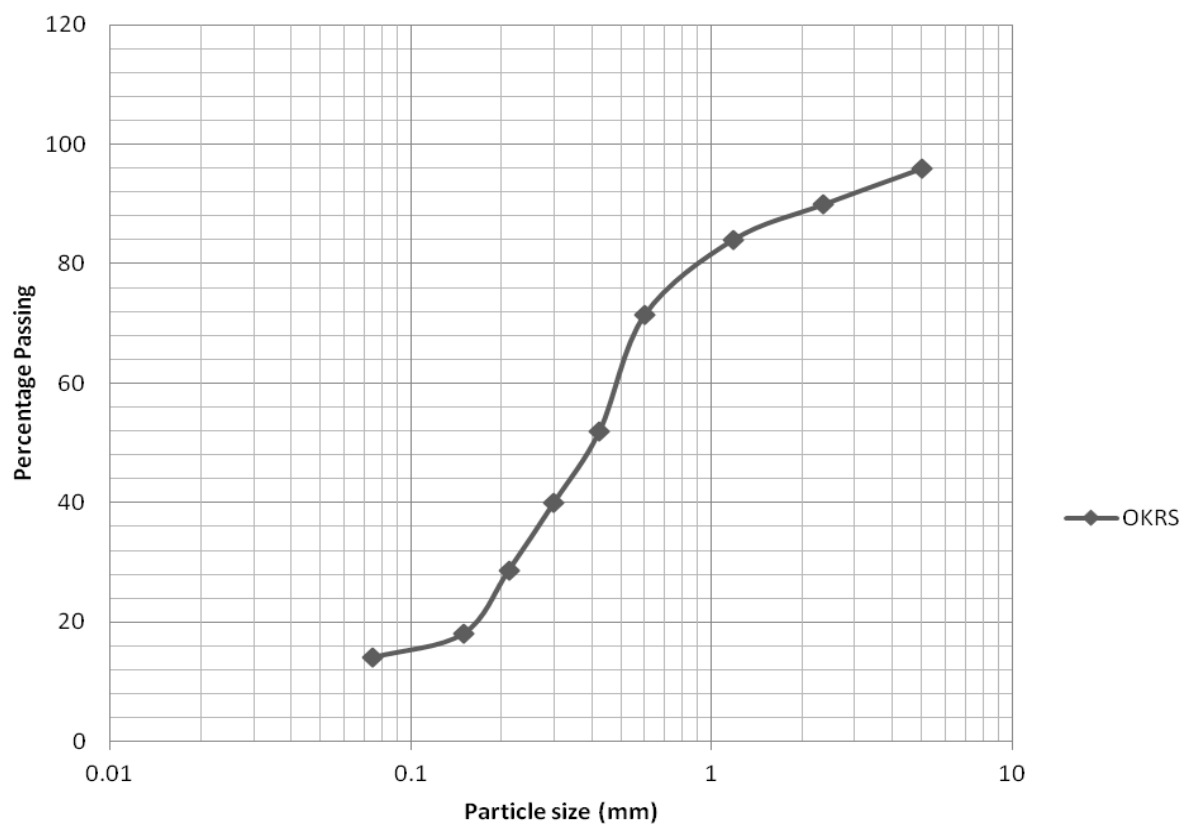


Figure 3. Grading curves for OKRS, OES and IFS on a semi-logarithmic plot.

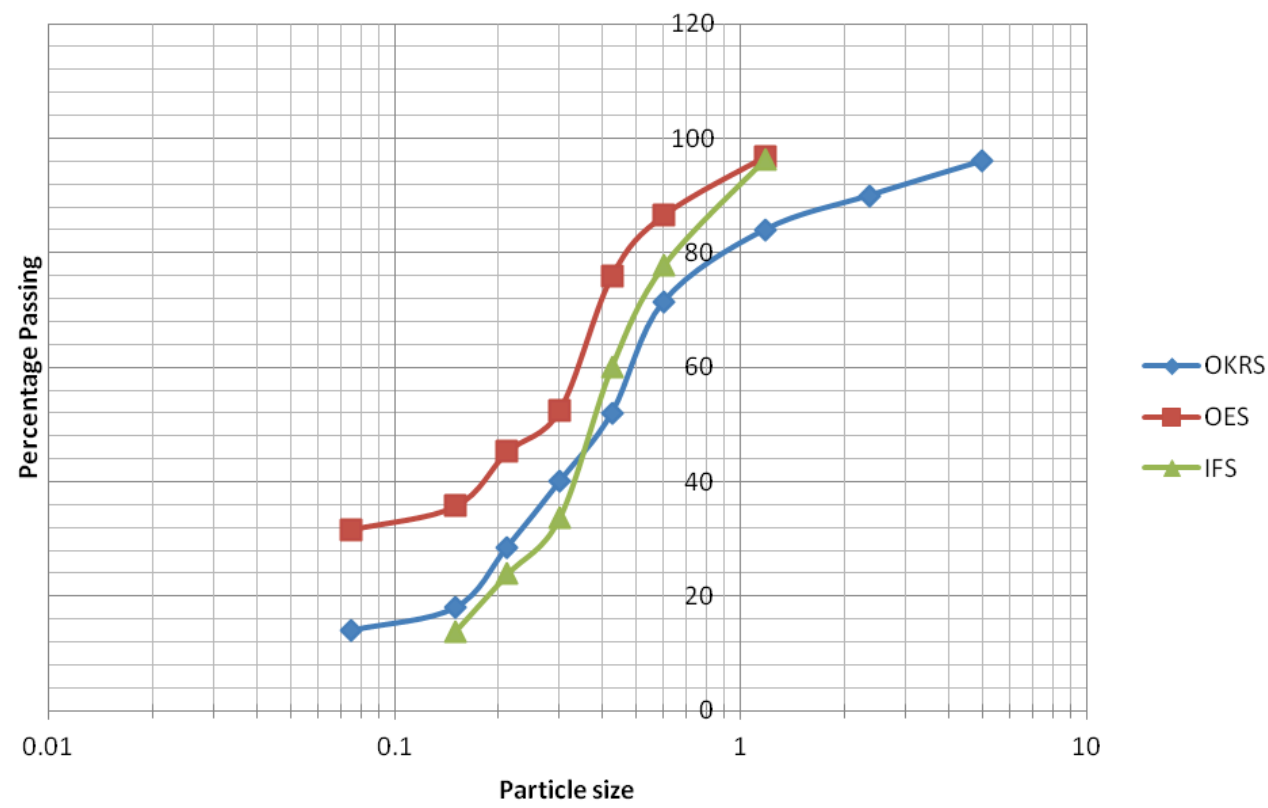

Figure 4. Grading curves for IFS and its various combinations with OKRS.

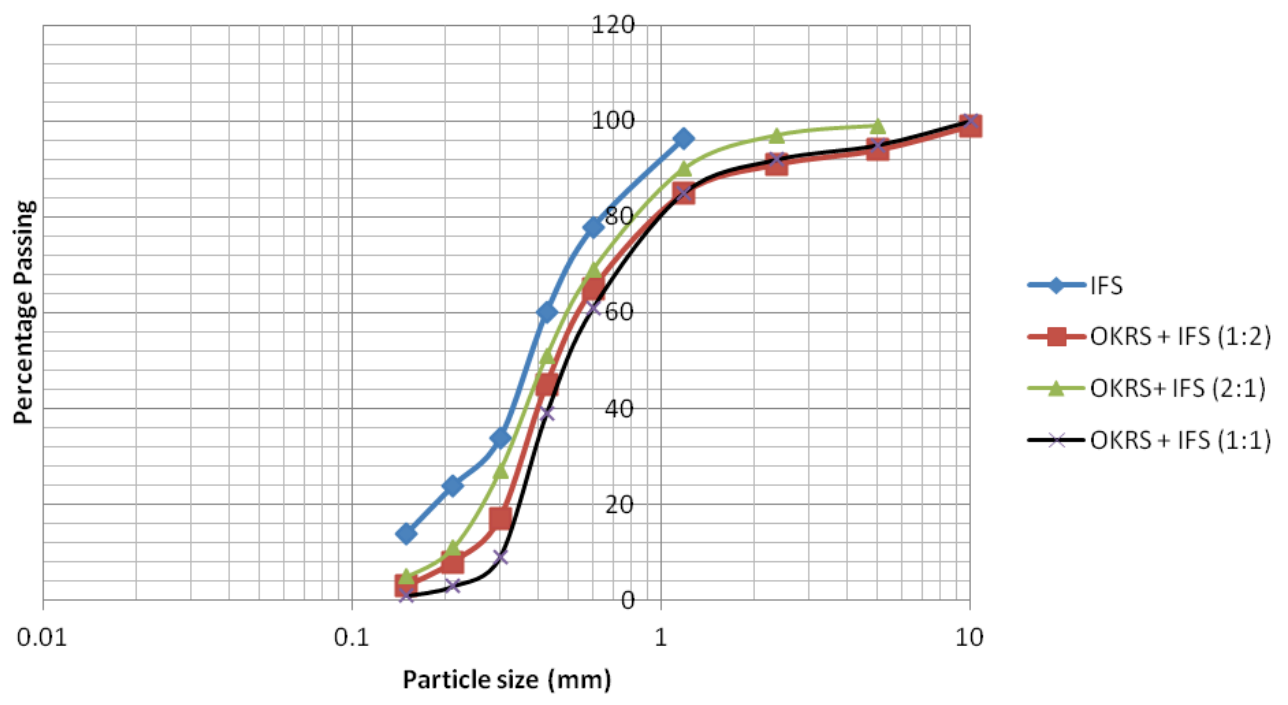


Figure 5. Grading curves for OES and its various combinations with OKRS.

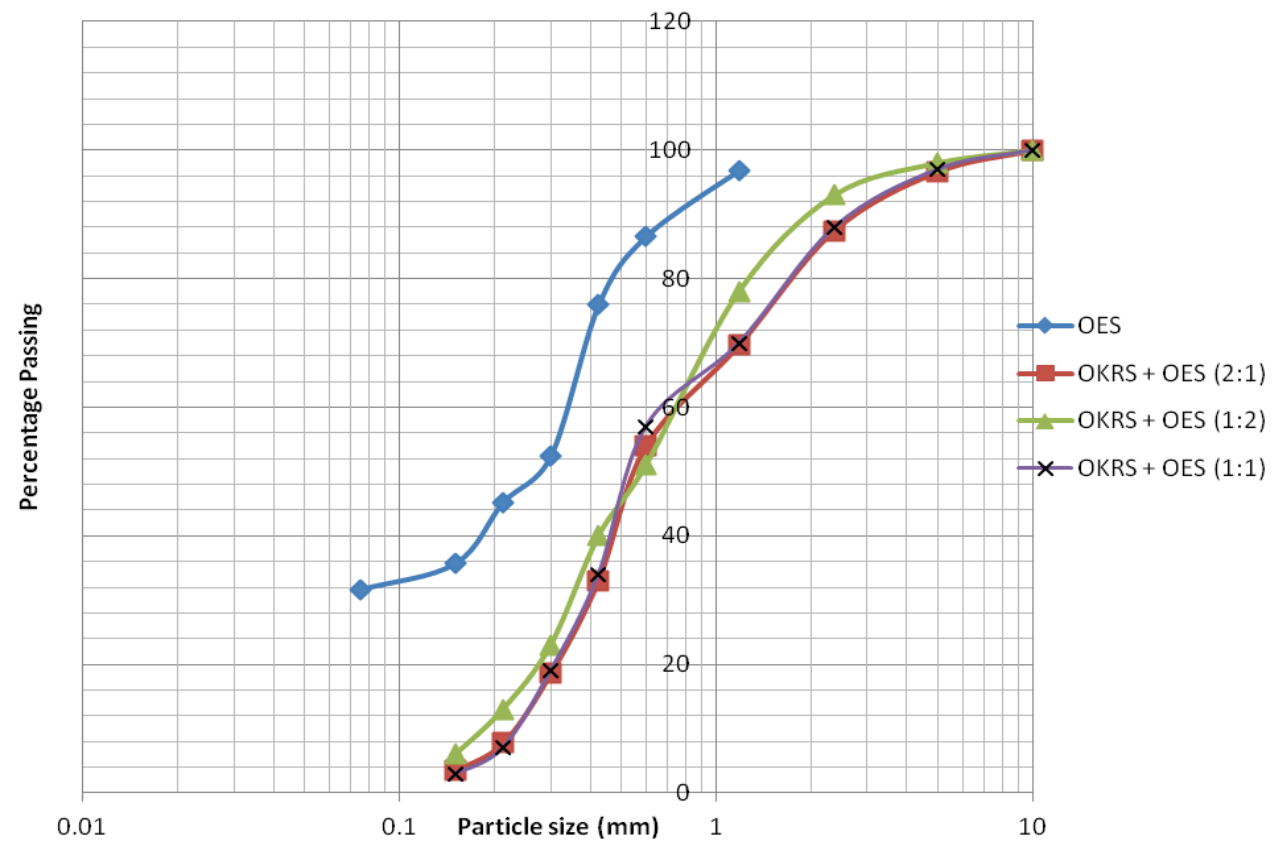

The uniformity coefficient $\left(\mathrm{C}_{\mathrm{u}}\right)$ defines the steepness of the curve on a semi-logarithmic plot and its value ranges from $\leq 2$ for poorly graded sand to $\geq 6$ for well graded sand [12]. Thus, the larger the $C_{u}$ the wider the particle size distribution and the smaller the $\mathrm{C}_{\mathrm{u}}$ the narrower the particle size distribution. If $\left(C_{u}\right)=1$ it means all particles (grains) are of the same size (uniform). $C_{u}$ is numerically expressed as follows:

$$
\begin{aligned}
C_{U} & =\frac{D_{60}}{D_{10}} \\
\therefore D_{60} & =C_{U} D_{10}
\end{aligned}
$$

where $D_{60}$ is the particular diameter at which $60 \%$ by weight of the sand is finer in size. $D_{10}$ is the particular diameter at which $10 \%$ by weight of the sand is finer in size.

The Curvature coefficients $\left(\mathrm{C}_{\mathrm{c}}\right)$ measures the mid-portion of the curve which defines the possibility for dense packing (width of the density function) and it also gives an indication of the shape of the grading curve (second moment or standard deviation of the curve). Its value ranges from 1 to 3 for well graded soil [12-14]. $\mathrm{C}_{\mathrm{c}}$ can also be numerically expressed as follows:

$$
C_{C}=\frac{D_{30} D_{30}}{D_{10} D_{60}}=\frac{D_{30}{ }^{2}}{D_{10} D_{10} C_{U}}=\frac{D_{30}{ }^{2}}{D_{10}{ }^{2} C_{U}}
$$

where $D_{30}$ is the particular diameter at which $30 \%$ by weight of the sand is finer in size.

See Table 5 for results of grading parameters of the sands and their various combinations. 


\subsection{Silt Content Test}

This was carried out using the standard decantation (field settlement) method in accordance with [15]. See Table 5 and Figure 8 for results of silt content.

\subsection{Sandcrete Block Production}

The sandcrete blocks were produced under highly controlled conditions. The mix ratio adopted was 1:6 (i.e., one part cement to six parts sand). The optimum moisture content from the compaction test conducted and the actual moisture content of the various sands were derived in accordance with the procedures in [11]. Thus, the actual proportion of water added to the mix was the difference between the optimum moisture content and the actual moisture content of the sand. This was carefully done in order not to exceed the optimum moisture content of the sand. However, the water/cement ratio employed was 0.80 . All batching was carried out by mass. In batching for example: $100 \mathrm{~kg}$ of sand with optimum moisture content of $11.7 \%$ at ratio 1:6 (sand-cement ratio) would require the following:

$$
\frac{100}{6}=16.3 \mathrm{Kg} \text { cement }
$$

$\therefore$ Bulk weight $=100+16.3=116.3 \mathrm{Kg}$

Optimum moisture content at $11.7 \%$ would require:

$$
\begin{gathered}
\frac{11.7 \times 116.3}{100}=13 \mathrm{Kg} \text { water } \\
\text { Water-cement ratio }=\frac{13}{16.3}=0.80
\end{gathered}
$$

The block molding machine used achieves compaction by combining vibration with compression. These vibrations were monitored for three sets of $225 \mathrm{~mm}$ and $150 \mathrm{~mm}$ blocks namely: 10 seconds, 20 seconds and 25 seconds before compression. Thus, a total of 1,080 blocks samples were produced.

\subsection{Compressive Strength Test}

Both the dry ${ }^{1}$ and wet ${ }^{2}$ compressive strength tests were carried out using the destructive test method. The compressive strength tests were carried out in accordance with [16]. See Tables 6-10 for results.

\footnotetext{
${ }^{1}$ The dry compressive strength test is the compressive strength test carried out on the blocks after the 28 day curing period.

${ }^{2}$ The wet compressive strength test is the test conducted after the 28 day cured blocks are submerged in water for another 14 days before undergoing the compressive strength test.
} 
Table 5. Result of various sand and sand combinations grading parameters and silt content values.

\begin{tabular}{|c|c|c|c|c|c|c|}
\hline \multirow{3}{*}{$\begin{array}{c}\text { Sand and } \\
\text { sand combinations }\end{array}$} & \multirow{3}{*}{$\begin{array}{c}\text { \% Passing } \\
\text { Sieve No. } 25\end{array}$} & \multirow{3}{*}{$\begin{array}{l}\text { Grading } \\
\text { zone }\end{array}$} & \multirow{3}{*}{$\begin{array}{c}\text { Fineness } \\
\text { Modulus }\left(\mathrm{F}_{\mathrm{m}}\right)\end{array}$} & \multirow{2}{*}{$\begin{array}{c}\text { Curvature } \\
\text { Coefficient }\left(\mathrm{C}_{\mathrm{c}}\right)\end{array}$} & \multirow{3}{*}{$\begin{array}{c}\text { Uniformity } \\
\text { Coefficient }\left(\mathrm{C}_{\mathrm{u}}\right) \\
=\frac{D_{60}}{D_{10}}\end{array}$} & \multirow{3}{*}{$\begin{array}{c}\text { Silt conten } \\
\%\end{array}$} \\
\hline & & & & & & \\
\hline & & & & $=\left(\frac{D_{30}^{2}}{D_{60} D_{10}}\right)$ & & \\
\hline OKRS & 71.45 & 3 & 3.14 & 1.500 & 7.05 & 1.106 \\
\hline OVRS & 85.20 & 4 & 3.09 & 1.350 & 2.11 & 1.512 \\
\hline OVES & 81.99 & 4 & 2.81 & 3.350 & 5.90 & 1.630 \\
\hline OKES & 77.80 & 3 & 2.95 & 1.540 & 3.81 & 1.860 \\
\hline IFS & 86.20 & 4 & 2.45 & 0.420 & 6.00 & 2.264 \\
\hline OES & 86.55 & 4 & 2.07 & 0.178 & 6.9 & 2.394 \\
\hline OKRS+OES $(2: 1)$ & 56.91 & 2 & 5.18 & 1.120 & 5.24 & - \\
\hline OKRS+OES $(1: 2)$ & 51.00 & 2 & 3.96 & 0.770 & 1.66 & - \\
\hline OKRS+OES $(1: 1)$ & 57.00 & 2 & 4.22 & 0.901 & 3.12 & - \\
\hline OVRS+OES $(2: 1)$ & 75.00 & 3 & 3.46 & 1.300 & 2.01 & - \\
\hline OVRS+OES (1:2) & 71.00 & 3 & 3.48 & 1.090 & 2.61 & - \\
\hline OVRS+OES $(1: 1)$ & 51.00 & 2 & 3.88 & 0.970 & 5.00 & - \\
\hline OKRS+IFS $(2: 1)$ & 69.00 & 3 & 3.50 & 0.970 & 2.54 & - \\
\hline OKRS+IFS (1:2) & 65.00 & 3 & 3.14 & 1.000 & 2.40 & - \\
\hline OKRS+IFS $(1: 1)$ & 61.00 & 3 & 4.10 & 0.830 & 1.95 & - \\
\hline OVRS+IFS (2:1) & 76.00 & 3 & 3.58 & 1.07 & 1.47 & - \\
\hline OVRS+IFS (1:2) & 77.00 & 3 & 3.56 & 1.22 & 1.42 & - \\
\hline OVRS+ IFS(1:1) & 79.00 & 3 & 3.52 & 1.11 & 1.52 & - \\
\hline
\end{tabular}


Table 6. Various OKRS combinations with OES, IFS and their wet and dry compressive strengths and percentage strength losses.

\begin{tabular}{ccccc}
\hline $\begin{array}{c}\text { Various OKRS } \\
\text { Combinations } \\
\text { With OES and IFS }\end{array}$ & $\begin{array}{c}\text { Combination } \\
\text { Ratio }\end{array}$ & $\begin{array}{c}\text { Dry } \\
\text { compressive } \\
\text { Strength } \\
\left(\mathbf{N} / \mathbf{m m}^{2}\right) \boldsymbol{d}\end{array}$ & $\begin{array}{c}\text { Wet compressive } \\
\text { Strength } \\
\left(\mathbf{N} / \mathbf{m m}^{2}\right) \boldsymbol{W}\end{array}$ & ' $\left[\left(\frac{d-w}{d}\right) 100\right]^{\prime}$ \\
\hline OKRS + OES & $1: 1$ & 5.02 & 2.94 & 41.10 \\
OKRS + OES & $1: 2$ & 4.71 & 2.85 & 39.50 \\
OKRS + OES & $2: 1$ & 4.92 & 3.05 & 38.00 \\
OKRS + IFS & $1: 1$ & 5.25 & 3.20 & 39.50 \\
OKRS + IFS & $1: 2$ & 5.01 & 3.16 & 37.00 \\
OKRS + IFS & $2: 1$ & 5.69 & 3.44 & 39.50 \\
\hline
\end{tabular}

Table 7. Average compressive strength values for $150 \mathrm{~mm}$ sandcrete blocks at 10 seconds, 20 seconds and 25 seconds vibration time.

\begin{tabular}{|c|c|c|c|c|c|c|c|c|c|}
\hline \multicolumn{10}{|c|}{ Average compressive strength values for $150 \mathrm{~mm}$ sandcrete blocks $\left(\mathrm{N} / \mathrm{mm}^{2}\right)$} \\
\hline \multirow[t]{2}{*}{$\begin{array}{c}\text { Vibration time } \\
\text { Name }\end{array}$} & \multicolumn{3}{|c|}{$\begin{array}{c}10 \text { seconds } \\
\text { Crushing day }\end{array}$} & \multicolumn{3}{|c|}{$\begin{array}{c}20 \text { seconds } \\
\text { Crushing day }\end{array}$} & \multicolumn{3}{|c|}{$\begin{array}{l}25 \text { seconds } \\
\text { Crushing day }\end{array}$} \\
\hline & 7 day & 14 day & 28 day & 7 day & 14 day & 28 day & 7 day & 14 day & 28 day \\
\hline OKRS & 1.51 & 1.70 & 2.05 & 3.02 & 3.40 & 4.10 & 3.75 & 4.20 & 5.11 \\
\hline OVRS & 1.41 & 1.61 & 2.04 & 2.78 & 3.17 & 4.03 & 3.6 & 4.01 & 5.04 \\
\hline OVES & 1.34 & 1.51 & 1.85 & 2.68 & 2.99 & 3.67 & 3.38 & 3.78 & 4.58 \\
\hline OKES & 1.28 & 1.43 & 1.78 & 2.56 & 2.88 & 3.55 & 3.23 & 3.61 & 4.44 \\
\hline IFS & 0.67 & 0.80 & 0.94 & 1.36 & 1.58 & 1.87 & 1.73 & 1.94 & 2.35 \\
\hline OES & 0.65 & 0.74 & 0.91 & 1.29 & 1.47 & 1.81 & 1.66 & 1.86 & 2.26 \\
\hline
\end{tabular}

Note: OKRS, Okhuahia river sand; OKES, Okhuahia erosion sand; OVRS, Ovia river sand; OVES, Ovia erosion sand; IFS, Ikpoba flood erosion sand; OES, Okhoro erosion sand.

Table 8. Average compressive strength values for $150 \mathrm{~mm}$ sandcrete blocks from the various sand combinations and vibration time.

\begin{tabular}{|c|c|c|c|c|c|c|c|c|c|}
\hline \multicolumn{10}{|c|}{ Average compressive strength values for $150 \mathrm{~mm}$ sandcrete blocks $\left(\mathrm{N} / \mathrm{mm}^{2}\right)$} \\
\hline \multirow[t]{2}{*}{$\begin{array}{c}\text { Vibration time } \\
\text { Name }\end{array}$} & \multicolumn{3}{|c|}{$\begin{array}{l}10 \text { seconds } \\
\text { Crushing day }\end{array}$} & \multicolumn{3}{|c|}{$\begin{array}{l}20 \text { seconds } \\
\text { Crushing day }\end{array}$} & \multicolumn{3}{|c|}{$\begin{array}{c}25 \text { seconds } \\
\text { Crushing day }\end{array}$} \\
\hline & 7 day & 14 day & 28 day & 7 day & 14 day & 28 day & 7 day & 14 day & 28 day \\
\hline OKRS and OES (2:1) & 1.12 & 1.75 & 2.34 & 2.28 & 3.69 & 4.68 & 3.05 & 4.33 & 4.65 \\
\hline OKRS and OES $(1: 2)$ & 1.04 & 1.42 & 1.67 & 2.09 & 2.82 & 3.33 & 2.68 & 3.84 & 3.99 \\
\hline OKRS and OES $(1: 1)$ & 1.09 & 1.51 & 2.18 & 2.16 & 3.12 & 4.38 & 2.68 & 4.00 & 4.44 \\
\hline OVRS and OES $(2: 1)$ & 1.10 & 1.62 & 1.71 & 2.22 & 3.24 & 3.41 & 2.78 & 3.95 & 4.23 \\
\hline OVRS and OES (1:2) & 0.97 & 1.36 & 1.58 & 1.94 & 2.71 & 3.12 & 2.43 & 3.37 & 3.88 \\
\hline OVRS and OES $(1: 1)$ & 1.09 & 1.61 & 1.77 & 2.14 & 3.19 & 3.54 & 2.68 & 4.00 & 4.40 \\
\hline OKRS and OVES (2:1) & 1.27 & 1.99 & 2.66 & 2.57 & 4.20 & 5.32 & 3.47 & 4.92 & 5.28 \\
\hline OKRS and OVES $(1: 2)$ & 1.18 & 1.61 & 1.89 & 2.36 & 3.18 & 3.77 & 2.98 & 4.00 & 4.65 \\
\hline OKRS and OVES $(1: 1)$ & 1.24 & 1.75 & 2.48 & 2.44 & 3.54 & 4.96 & 3.05 & 4.55 & 5.04 \\
\hline OVRS and OVES $(2: 1)$ & 1.36 & 1.98 & 2.08 & 2.70 & 3.91 & 4.16 & 3.42 & 4.86 & 5.20 \\
\hline OVRS and OVES $(1: 2)$ & 1.14 & 1.58 & 1.84 & 2.27 & 3.15 & 3.64 & 2.84 & 3.94 & 4.55 \\
\hline OVRS and OVES $(1: 1)$ & 1.20 & 1.79 & 2.50 & 2.37 & 3.57 & 5.00 & 3.00 & 4.46 & 4.93 \\
\hline
\end{tabular}


Table 8. Cont.

Note: OKRS, Okhuahia river sand; OKES, Okhuahia erosion sand; OVRS, Ovia river sand; OVES, Ovia erosion sand; IFS, Ikpoba flood erosion sand; OES, Okhoro erosion sand.

Table 9. Average compressive strength values for $225 \mathrm{~mm}$ sandcrete blocks at 10 seconds, 20 seconds and 25 seconds vibration time.

\begin{tabular}{cccccccccc}
\hline \multicolumn{3}{c}{ Average compressive strength values for 225 mm sandcrete blocks $\mathbf{( N / \mathbf { m m } ^ { 2 } )}$} \\
\hline $\begin{array}{c}\text { Vibration time } \\
\text { Name }\end{array}$ & \multicolumn{3}{c}{$\begin{array}{c}\text { 10 seconds } \\
\text { Crushing day }\end{array}$} & \multicolumn{3}{c}{$\begin{array}{c}\text { 20 seconds } \\
\text { Crushing day }\end{array}$} & \multicolumn{3}{c}{$\begin{array}{c}\text { 25 seconds } \\
\text { Crushing day }\end{array}$} \\
\hline & $\mathbf{7 ~ d a y}$ & $\mathbf{1 4}$ day & $\mathbf{2 8}$ day & $\mathbf{7 ~ d a y}$ & $\mathbf{1 4}$ day & $\mathbf{2 8 ~ d a y}$ & $\mathbf{7 ~ d a y}$ & $\mathbf{1 4}$ day & $\mathbf{2 8 ~ d a y}$ \\
\hline OKRS & 1.38 & 2.22 & 2.36 & 2.85 & 4.37 & 4.53 & 3.64 & 5.53 & 5.59 \\
OVRS & 1.42 & 1.47 & 1.56 & 2.59 & 4.13 & 4.16 & 3.54 & 5.39 & 5.53 \\
OVES & 1.32 & 1.75 & 2.01 & 2.55 & 3.90 & 4.01 & 3.18 & 4.88 & 5.02 \\
OKES & 1.36 & 1.44 & 1.49 & 2.47 & 3.93 & 3.96 & 3.34 & 5.14 & 5.28 \\
IFS & 1.06 & 1.14 & 1.50 & 1.67 & 1.70 & 2.09 & 1.79 & 2.10 & 2.57 \\
OES & 0.64 & 0.84 & 1.40 & 1.22 & 1.63 & 2.00 & 1.52 & 2.00 & 2.47 \\
\hline
\end{tabular}

Table 10. Average compressive strength values for $225 \mathrm{~mm}$ sandcrete blocks from the various sand combinations and vibration time.

\begin{tabular}{|c|c|c|c|c|c|c|c|c|c|}
\hline \multicolumn{10}{|c|}{ Average compressive strength values for $225 \mathrm{~mm}$ sandcrete blocks $\left(\mathrm{N} / \mathrm{mm}^{2}\right)$} \\
\hline \multirow[t]{2}{*}{$\begin{array}{c}\text { Vibration time } \\
\text { Name } \\
\end{array}$} & \multicolumn{3}{|c|}{$\begin{array}{c}10 \text { seconds } \\
\text { Crushing day }\end{array}$} & \multicolumn{3}{|c|}{$\begin{array}{c}20 \text { seconds } \\
\text { Crushing day }\end{array}$} & \multicolumn{3}{|c|}{$\begin{array}{c}25 \text { seconds } \\
\text { Crushing day } \\
\end{array}$} \\
\hline & 7 day & 14 day & 28 day & 7 day & 14 day & 28 day & 7 day & 14 day & 28 day \\
\hline OKRS and OES $(2: 1)$ & 1.28 & 1.75 & 2.04 & 2.64 & 3.56 & 4.28 & 3.37 & 4.88 & 4.92 \\
\hline OKRS and OES (1:2) & 1.19 & 1.74 & 1.90 & 2.38 & 3.53 & 3.81 & 2.94 & 4.34 & 4.71 \\
\hline OKRS and OES (1:1) & 1.20 & 1.97 & 1.99 & 2.57 & 3.84 & 3.98 & 3.13 & 4.84 & 5.02 \\
\hline OVRS and OES $(2: 1)$ & 1.18 & 1.80 & 1.91 & 2.33 & 3.62 & 3.92 & 3.00 & 4.50 & 4.85 \\
\hline OVRS and OES (1:2) & 0.94 & 1.54 & 1.74 & 2.00 & 3.21 & 3.46 & 2.80 & 4.00 & 4.45 \\
\hline OVRS and OES (1:1) & 1.00 & 1.61 & 2.12 & 2.32 & 3.09 & 4.10 & 2.88 & 4.58 & 5.00 \\
\hline OKRS and OVES $(2: 1)$ & 1.44 & 1.99 & 2.32 & 3.00 & 4.04 & 4.84 & 3.81 & 5.55 & 6.05 \\
\hline OKRS and OVES $(1: 2)$ & 1.34 & 1.98 & 2.16 & 2.68 & 4.01 & 4.31 & 3.33 & 4.93 & 5.33 \\
\hline OKRS and OVES $(1: 1)$ & 1.36 & 2.24 & 2.26 & 2.92 & 4.35 & 4.51 & 3.56 & 5.49 & 5.70 \\
\hline OVRS and OVES $(2: 1)$ & 1.23 & 1.96 & 2.54 & 2.96 & 4.00 & 4.80 & 3.75 & 5.47 & 5.96 \\
\hline OVRS and OVES $(1: 2)$ & 1.28 & 1.74 & 2.10 & 2.55 & 3.68 & 4.00 & 3.29 & 4.87 & 5.22 \\
\hline OVRS and OVES $(1: 1)$ & 1.27 & 2.21 & 2.40 & 2.75 & 4.00 & 4,41 & 3.50 & 5.41 & 5.60 \\
\hline OKRS and IFS (2:1) & - & - & - & - & - & - & 3.58 & 5.22 & 5.69 \\
\hline OKRS and IFS (1:2) & - & - & - & - & - & - & 3.13 & 4.63 & 5.01 \\
\hline OKRS and IFS (1:1) & - & - & - & - & - & - & 3.35 & 5.16 & 5.25 \\
\hline OVRS and IFS (2:1) & - & - & - & - & - & - & 3.52 & 5.14 & 5.60 \\
\hline OVRS and IFS (1:2) & - & - & - & - & - & - & 3.00 & 4.48 & 4.95 \\
\hline OVRS and IFS (1:1) & - & - & - & - & - & - & 3.31 & 5.12 & 5.20 \\
\hline
\end{tabular}

\subsection{Durability Test}

The shower spray method was used. The aim was to assess the resistance of the block to the effects of a storm or driving rain i.e., above $508 \mathrm{~mm}$ of annual rainfall [17]. This was achieved by subjecting 
the block samples to $1.5 \mathrm{~kg} / \mathrm{cm}^{2}$ (22 psi) pressure of water for two hours. It was carried out with a $100 \mathrm{~mm}$ diameter shower head clamped vertically above the block. The block was weighed and turned sideways i.e., its largest face in the horizontal position facing the showerhead, at a distance of $200 \mathrm{~mm}$. Finally, a visual inspection and weighing was carried out to ascertain the extent of pitting and weight loss. See Tables 6 and 7 for wet compressive strength results.

\section{Discussion}

Figure 6. Compressive strength at 7, 14 and 28-day test for all the various sands.

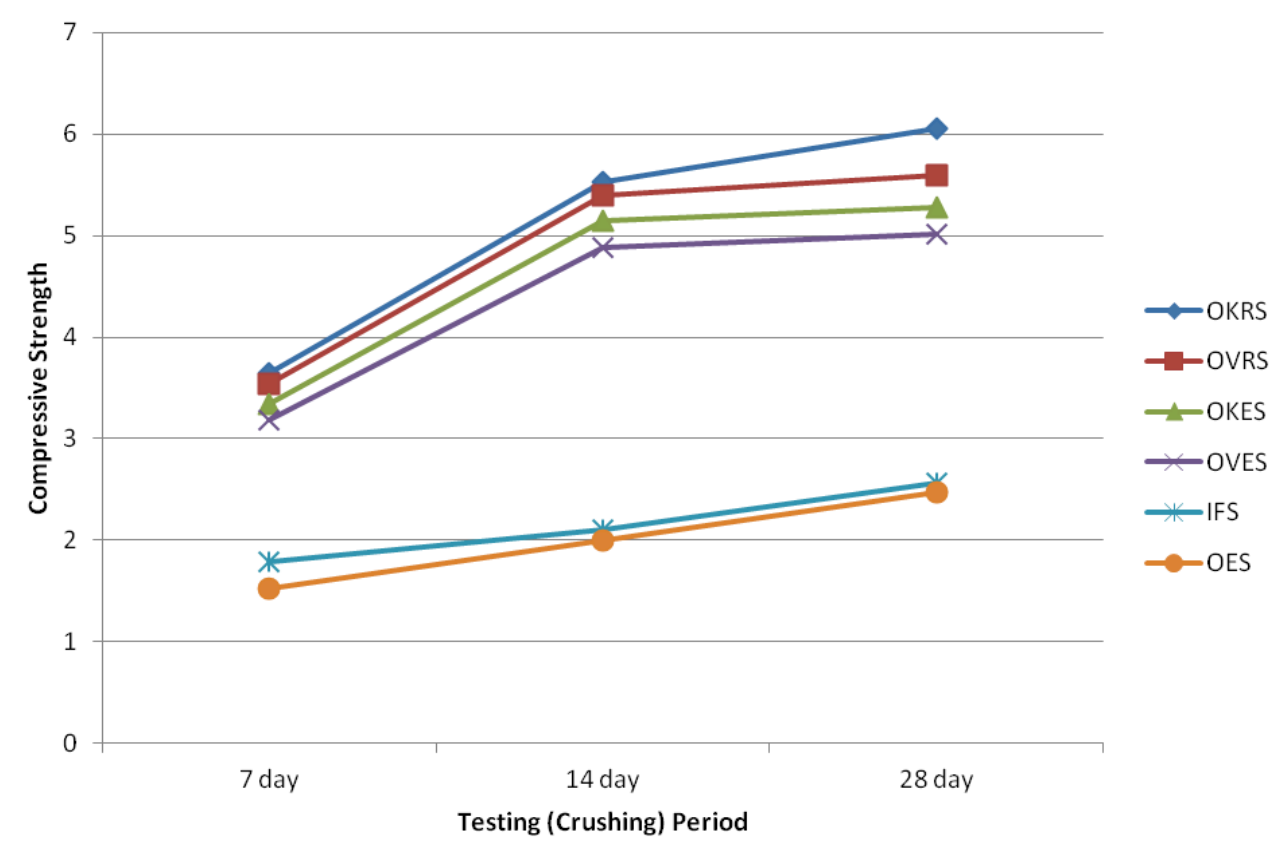

Figure 7. Compressive strength at 7, 14 and 28-day testing period for OES and its combinations.

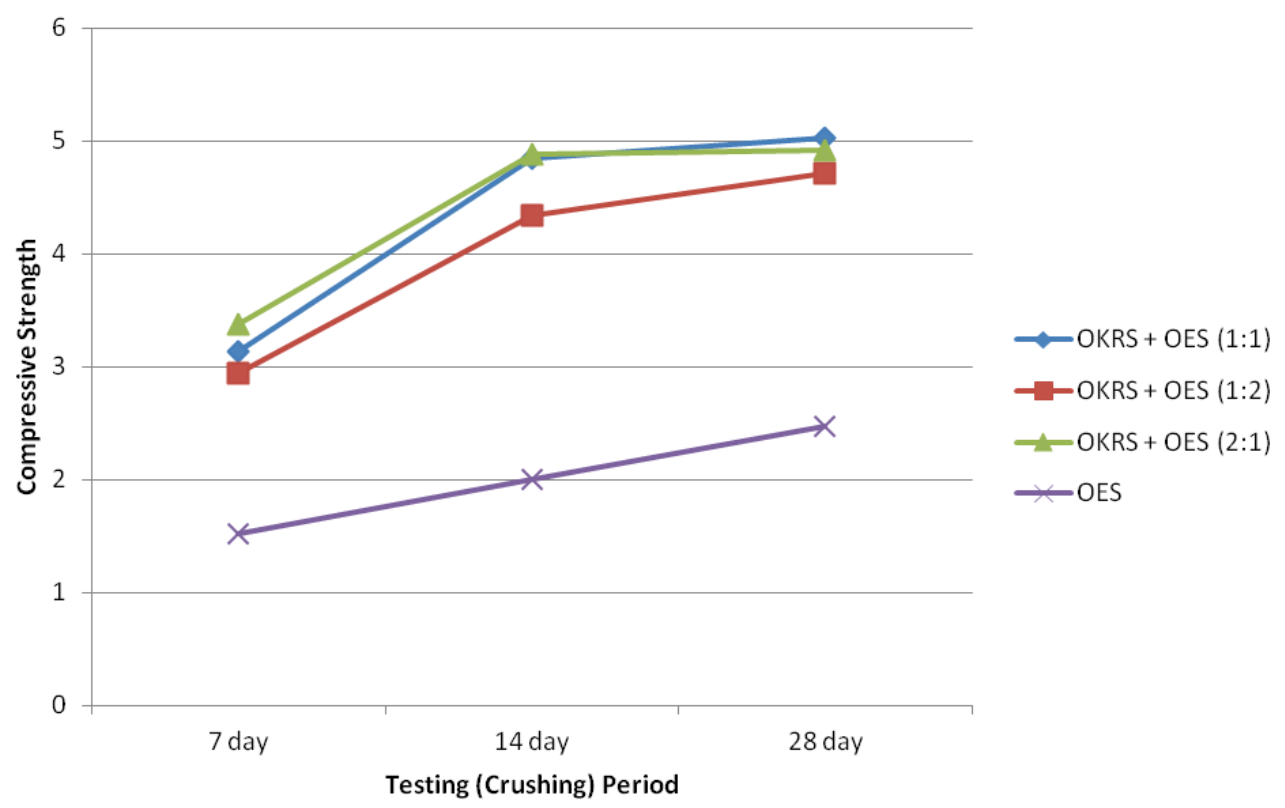


Figure 8. Silt content profile of all the various sands.

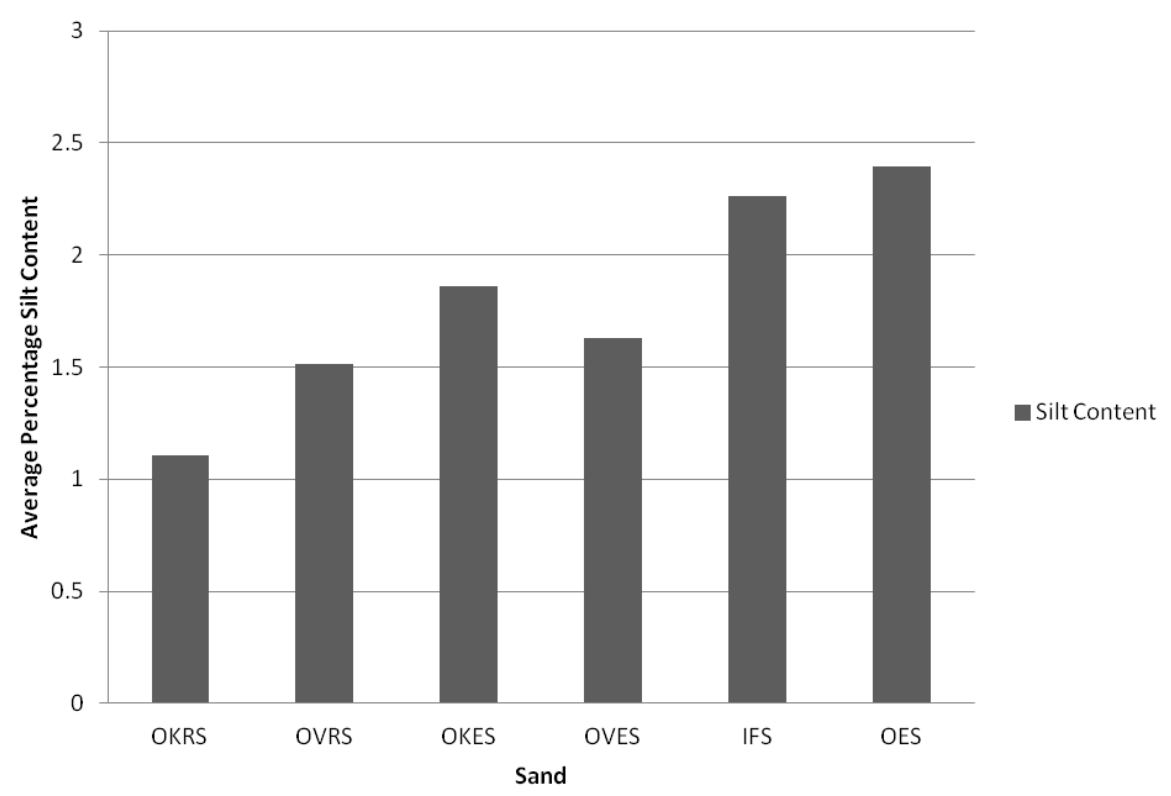

From the compressive strength results tables (Tables 7 and 9) and plotted graphs (Figure 6 and 7) for all the various sand samples (excluding combinations); the highest compressive strengths were recorded at the 28-day crushing test and 25 seconds vibration time. OKRS gave the highest compressive strength at 7-day, 14-day and 28-day respectively. The next was OVRS; this was followed by OKES and then OVES. However, the last two: IFS and OES had compressive strength values that were much lower compared with the likes of OKRS, OVRS, OKES, and OVES. OES recorded the lowest compressive strength.

From the silt content test results, it was revealed that OES had the highest percentage silt content. This was followed by IFS and then OVES, OKES and OVRS. OKRS had the least silt content (see Figure 8; Table 5). Nevertheless, the minimum allowable percentage silt content was not surpassed by any of the sands. What is noticeable from these results, is that with increasing silt content and reduced vibration periods, the compressive strength depreciates.

The particle size distribution test (i.e., sieve analysis) carried out to ascertain the grading parameters of each of these sands showed that OKRS was the best sand in every measure in comparison to the others (see Table 5, Figures 3 and 4). Generally, the grading performance of each of these sands was similar to their relative positions or performance during the compressive strength test. For example, the grading performance of OES was poor because of its high silt content in comparison to the others (see Table 5 and Figures 3, 4 and 8). This might have led to an increase in the water-cement ratio for a given workability which in turn reduced the compressive strength. Thus, strength is partly related to the level of silt content in sands. It is 'partly related' because several other factors outside constituent materials affect strength i.e., method of preparation, curing and test conditions $[18,19]$.

OES on the other hand exhibited poor grading parameters, compressive strength and much higher silt content. Notwithstanding this, OES is still the most widely used sand in Benin City and its environs because it is readily available.

In the bid to maximize the utility value of both OKRS and OES, a combination approach was employed: OES (with the weakest engineering properties) combined with OKRS (with better 
engineering properties) at ratios 1:1, 2:1 and 1:2. Similarly, OKRS and IFS were blended together at the same ratios and these were repeated combining OVRS with OES and OVRS and IFS. The results were encouraging. It was observed that the compressive strengths of all the block samples were higher with increasing vibration periods during production i.e., the highest compressive strength was recorded at 25 seconds vibration time; followed by 20 seconds vibration time and 10 seconds respectively. Thus, strength is also partly related to the vibration periods or levels of compaction. Of particular interest was the combination of OKRS with OES and OKRS with IFS. Here, the results of the wet compressive strength test at 14-day and 25 seconds vibration time were within the range of 37 percent to 41 percent less than their dry compressive strength values. This comparison was necessary in view of the prevalent exposure conditions these blocks might be subjected to in future, for example natural flooding and failed infrastructures (e.g., broken pipes in the water supply network, drainage systems and sanitation). Information such as this would assist developers or builders in how to use these blocks particularly in the riverine areas and water logged soils like the Niger-delta region of Nigeria. It should also be noted that blocks used for external cladding and boundary walls which are subject to driving rain or water logged soil are either partially or fully soaked with water. This affects the compressive strength and durability properties. For this reason, it is necessary to determine the wet compressive strength of the blocks after soaking in water for 14 days [20]. In addition, samples from these relative combinations i.e., OKRS and OES; OKRS and IFS yielded very high compressive strength increases over those of OES, IFS when used individually (Tables 7-10). The range increase was from 99 percent to 103 percent for the OKRS and OES blend alone (Table 6).

\section{Recommendations}

Since vibration time was significant in compressive strength and durability of sandcrete blocks, future investigation needs to establish an optimum vibration time relevant to materials and circumstances. In addition, increasing the vibration time beyond what is currently employed (which is about 10-15 seconds) should be emphasized during block manufacture.

To maximize the utilization of fine aggregate like Okhoro river sand (OES) and Ikpoba flood erosion (IFS) sand in Benin City, the combination with superior sands such as Okhuahia river sand (OKRS) is strongly recommended. It is expected that similar problems could be tackled using this technique. The blending must not be carried out arbitrarily otherwise the objectives will be defeated. Rather, it should be practically measured on site by mass or by volume (since the cost of weighing machines is far beyond the reach of an average builder or developer in Nigeria). Efforts should also be geared towards knowing the actual moisture content and the optimum moisture content of the sand combinations to achieve the best water-cement ratio for the best possible performance as this would assist in eradicating concerns of workability and sand buckling. Further work needs to be carried out to ascertain the geotechnical properties of these combinations in comparison to those of the individual fine aggregates.

There is also a need to establish the optimum mix ratio of each sand combination as a guide for best performance. A similar investigation of this magnitude where pozollanic materials and admixtures are used as binders should also be considered in the future for economic reasons and in view of the energy intensive and the environmental impact of the use and manufacture of Portland cement. 
For external walls and in areas where these blocks are exposed to moisture (ingress), after laying, the surfaces should be well rendered. Below ground level, the surfaces should be coated with a water proofing agent e.g., bitumen. Waterproof Portland cement could be used for the laying, manufacture and rendering of sandcrete blocks to prevent moisture ingress. This cement contains waterproofing agents so blocks made with it are less permeable to water. The objective is to fill the pores of the mortar or to line the pores with a film of water repellent material.

Owing to the skilled manpower required for the manufacture and use of sandcrete blocks and relevant quality control processes in developing countries like Nigeria, subsidized further education (technical colleges) tuition and other forms of incentivized training schemes should be encouraged to cater for skill gaps in these areas. In addition, an appropriate regulatory framework should be put in place to monitor, and enforce where necessary, quality control processes in the making of sandcrete blocks.

\section{Conclusion}

Most frequently used sands in Nigeria are poorly graded and the blocks made from these sands are also poorly produced. This has been indirectly responsible for the high failure rates of sandcrete blocks. Usually, poorly graded sand would require a high water-cement ratio which seriously affects compaction of sandcrete blocks. It is difficult to specify a fixed vibration time economically viable for each producer without the relevant knowledge of the materials and technology that is applicable and available to them (18-25 seconds vibration time is generally recommended in Nigeria). This is hardly ever enforced or adhered to. It is also of note that the characteristics of fine aggregates have a considerable influence on the mix proportions and on the economy of sandcrete. Therefore, fine aggregate should consist of clean, hard, durable particles free from a coating of clay or other fine aggregate capable of influencing the bond of the cement paste. Contaminating substances most often encountered are dirt, silt, clay, mica, salts and humus or other organic matter that may appear as coating or as loose fine material. However, these substances can be removed by washing. A physical examination could be used as a simple, preliminary method of identifying suitable sand(s) for block production. The cleaner and grittier the sand is between the fingers, the better the sand is. Silt by comparison feels almost like flour.

Lastly, increasing the vibration time of sandcrete, blending sands during production or a combination of the two, undoubtedly improves the compressive strength and durability properties and also maximizes the use of these poorly graded sands.

\section{Acknowledgments}

Appreciation goes to Tim Parker, from Leicester; Anselm Kersten, De Montfort University Kimberlin Library Leicester; for their support and proofreading of this paper. 


\section{References}

1. Alutu, O.E. Wind Induced Failure of Pavilion Roof in Ekpoma, Implication for structural design and construction. Tech. Trans. 2000, 5, 15-20.

2. Okolie, K.; Akagu, C. Quality control in building delivery process. Niger. Inst. Arch. 1994, 3-5.

3. Okpalla, D.; Ihaza, J. Quality of Sandcrete Blocks Produced in Benin City. In Proceedings of the 1st Uniben Conference on Engineering and Technological Development, Benin City, Nigeria, 1987.

4. Olusola, B.; Akintayo, O. An Assessment of failure of building component in Nigeria. J. Build. Apprais. 2009, 4, 279-286.

5. Illston, J.; Dinwoodie, J.; Smith, A. Concrete, Timber and Metals; Reenold Company: Van Nostrand, New York, NY, USA, 1979.

6. Nwokoye, D. The Philosophical Bases in Education and Practice of Structural Engineering; Ambik Press: Benin City, Nigeria, 1999.

7. Omoregie, A.; Alutu, O. The influence of fine aggregate combinations on particle size distribution, grading parameters and compressive strength of sandcrete blocks. Can. J. Civ. Eng. 2006, 33, 1271-1278.

8. Florek, A. Quality of Sandcrete Hollow Blocks Manufactured in Nigeria. In Proceedings of the Conference on Material Control and Research, University of Lagos, Lagos, Nigeria, 1985.

9. Banuso, O.; Ejeh, S. Assessment of quality of sandcrete blocks in Kaduna State, Nigeria. J. Constr. 2008, 2, 11-15.

10. Oyetola, E.; Abdullahi, M. The use of rice husk ash in low-Cost sandcrete block production. Leonardo Electron. J. Pract. Technol. 2006, 8, 58-70.

11. BSI British Standards. Methods of Test for Soils for Civil Engineering Purposes; BSI: London, UK, 1990; BS 1377 Part 1 and 2.

12. Jackson, N.; Dhir, R. Civil Engineering Materials; Macmillian Press: London, UK, 1996.

13. WEST, T. Geology Applied to Engineering; Prentice Hall: Upper Saddle River, NJ, USA, 1995.

14. Tezaghi, K.; Peck, R.; Mesri, G. Soil Mechanic in Engineering Practice, 3rd ed.; John Wiley and Sons: New York, NY, USA, 1996.

15. BSI British Standards. Testing Aggregates. Method for Determination of Particle Size Distribution. Sieve Tests; BSI: London, UK, 1985; BS 812 Part 103.

16. BSI British Standards. Precast Concrete Masonry Units: Specification for Precast Concrete; BSI: London, UK, 1981; BS 6073 Part 1.

17. Fitzmaurice, R. Manual of Stabilized Soil Construction for Housing; Technical Association: New York, NY, USA, 1958.

18. Neville, A. Properties of Concrete; Longman: Harlow, Essex, UK, 1996.

19. Neville, A.; Brooks, J. Concrete Technology; Scientific and Technical: London, UK, 1994.

20. The Nigerian Industrial Standards (NIS). Draft Code of Practice for Sandcrete Blocks; Federal Ministries of Industries, NIS: Lagos, Nigeria, 1975.

21. Baiden, B.K.; Tuuli, M. Impact of quality control practices in sandcrete blocks production. J. Arch. Eng. 2004, 10, 55-60. 
22. Anosike, M.N.; Oyebade, A.A. Concrete blocks and quality management in nigeria building industry. J. Eng. Proj. Prod. Manag. 2012, 2, 37-46.

23. The Institution of Structural Engineers (IStructE). Manual for the Design of Plain Masonry in Building Structures to Eurocode 6; The Institution of Structural Engineers: London, UK, 2008.

24. Eurocode 6: BS EN 1996-1-1: 2005. Design of Masonry Structures. General Rules for Reinforced and Unreinforced Masonry Structures; BSI: London, UK, 2005.

25. UK National Annex to Eurocode 6: NA to BS EN 1996-1-1: 2005. Design of Masonry Structures. General Rules for Reinforced and Unreinforced Masonry Structures; BSI: London, UK, 2007.

26. The State of Queensland (Department of Environment \& Resource Management). Coastal Sand Dunes-Their Vegetation and Management: The Formation and Function of Coastal Dunes; Queensland Government: Queensland, Australia, 2012.

(C) 2012 by the authors; licensee MDPI, Basel, Switzerland. This article is an open access article distributed under the terms and conditions of the Creative Commons Attribution license (http://creativecommons.org/licenses/by/3.0/). 